\title{
Contribution of Compensation, Work Environment and Motivation Against Work Productivity: A Case Study of BPS Partner Personnel of Ngawi Regency
}

\author{
A.R. Djoko Purwito ${ }^{1} \square$ Rachmawati $K^{2}$ and Rozalina Novianty ${ }^{3}$ \\ ${ }^{123}$ Prodi Manajemen Univ. Soerjo, Indonesia \\ $\square$ Corresponding Author: A.R. Djoko Purwito, E-mail: arj.poerwito@gmail.com
}

\begin{abstract}
ARTICLE INFORMATION ABSTRACT
Received: 01 August 2021

Accepted: 28 September 2021

Published: 14 October 2021

DOI: 10.32996/jbms.2021.3.2.14

\section{KEYWORDS}

This research is intended to examine the contribution of compensation, work environment, and work motivation to work productivity in a manner partially and simultaneously. To the end, the study used the Path Analysis Model of Decomposition, which analyzes the influence of causality between research variables (Riduwan: 2008). The results of the study showed that compensation, work environment, and work motivation contribute significantly to the work productivity of BPS Mitra Ngawi Regency 2019.
\end{abstract}

Compensation, work environment,

work motivation, work productivity

\section{Introduction}

In organizational activities both in the form of institutions and companies, productivity is one of the important factors for the development of an institution or company. This can be interpreted, if productivity is higher, then the development of institutions or companies is also increasingly positive. Productivity is in principle the utilization of all elements of human resources owned by an institution or company to produce products or work to the maximum so that it is expected that institutions or companies will continue to exist and develop. When viewed from the object of research, then productivity here is the result of work done by Mitra BPS Ngawi Regency personnel in helping to handle BPS projects in Ngawi Regency.

From the literature study, it can be known that many factors can affect work productivity. For example, the compensation factor, namely a certain amount of money or direct or indirect goods received by each person or worker in return for the services of work he has done (Hasibuan, 2007). In connection with this, compensation closely relates to worker satisfaction. This is reflected in the greater the complement will be followed the higher the level of worker satisfaction. Related to this James Sherk (2013) writes that if the level of worker satisfaction is high is expected followed by high productivity as well. Furthermore, James Sherk stated that the increase in compensation tends to be followed by a rise in productivity, or in other words the tendency of increases in compensation and increases in productivity to move in linear lines.

Another factor that has the potential to affect work productivity is the work environment, namely the environment where workers' work activities can be both physical and non-physical environments (Sedarmayanti: 011). To be able to achieve high productivity every worker needs a comfortable environment. This can be a good relationship between workers, a conducive atmosphere such as no noise, cool air and so on. That way every worker will feel comfortable in work so that it can affect their work productivity. This is in line with the results of research by Alvin et al (2018) which concluded that the work environment has a significant effect on employee work productivity.

Furthermore, the factor that affects work productivity is work motivation, which is the encouragement from within a person to do something work to achieve a goal (As'ad: 2005). This factor also has the potential to greatly affect work productivity. This is evident from the results of Mulyadi's research (2010) which in its conclusions included that motivation and compensation simultaneously

Copyright: (c) 2021 the Author(s). This article is an open access article distributed under the terms and conditions of the Creative Commons Attribution (CC-BY) 4.0 license (https://creativecommons.org/licenses/by/4.0/). Published by Al-Kindi Centre for Research and Development, London, United Kingdom. 
significantly affect employee productivity. In addition, Nahavand in Jih-Hua (2017) on the results of his research stated that a person's positive feelings can evoke positive emotions so that in the end it is able to encourage increased productivity of work. In addition to these factors, there are many other factors that have the potential to affect work productivity but are not included in this study.

Based on the various problems above, this research seeks to reveal the contribution of compensation, work environment, and work motivation to the labor productivity of BPS Mitra of Ngawi Regency in 2019 both partially and simultaneously.

\section{Literature Review}

\subsection{Review of Compensation with Work Productivity}

As has been stated in his book Hasibuan (2007) that compensation is a sum of money or goods that each worker receives in return for the services of the work he has done. While work productivity according to Sutrisno (2009) is an ability of a worker to produce a job or product compared to the input used. So, an employee is declared productive if able to complete the work according to or exceeding the target set. These two factors are closely related to each other. This is reflected in the results of Bolanle et al research (2014) that compensation affects employee performance and increases productivity. Similarly, the results of Emmanual research (2013) also stated that compensation has a significant effect on labor productivity. Furthermore, it was also stated that the results of his research showed the fact that productivity depends on the level of satisfaction of workers for the compensation they receive. The same is also seen from the results of research that concludes that wages and incentives partially have a significant effect on work productivity (Vellina: 2012).

\subsection{Study of the Work Environment with Work Productivity}

The work environment is all the tools and materials that are used to work, the environment, the methods used, and the work system both as an individual and as a group (Sedarmayanti:2011). Similarly, according to Nitisemito (2007), the work environment is everything around workers that can affect themselves in carrying out their work tasks. The work environment is closely related to work productivity. This is evident from the results of research that states that the work environment and work skills have a significant effect on employee work productivity in the Black Crow cigarette factory of Maesan District Bondowoso district (Alvin et al:2018). In addition, it is also seen from the results of Kumbadewi et al (2016) research that concluded that there is simultaneous and partial environment work to the productivity.

\subsection{Study of Motivation with Work Productivity}

Motivation is the encouragement in a worker both physical and spiritual to do a job to achieve an organizationally defined goal (As'ad: 2005). Motivational factors are closely related to work productivity. This is evident from the results of Mulyadi's research (2010) which states that motivation and tension all together have a significant effect on employee productivity in PT. Galamedia Bandung Perkasa. In addition, it is also reflected in the results of Ibrahim's research (2013) which concluded that motivation can increase productivity. The same thing is also seen from the results of Nahavand's research in Jih-Hua (2017) which states that the ability of someone who continues to encourage work motivation will be able to increase work productivity.

\subsection{Hypothesis}

Compensation, work environment, and work motivation partially and simultaneously contribute significantly to the labor productivity of Mitra BPS Ngawi Regency.

\section{Research Methodology}

\subsection{Operationalization of Research Variables}

1) Compensation (X1)

Compensation is a sum of money or goods received by each Partner Power

BPS Ngawi Regency in return for the work he has done. The indicators to measure these variables are: a) Appreciation for creativity; b) Appreciation for achievement; c) Tolerance of working hours; d) There is attention; e) Basic salary; f) Incentivizing; g) Giving money to eat.

2) Work Environment (X2)

The environment of work is everything that is around the workers of Mitra BPS Ngawi regency that can affect him in carrying out his work tasks. The indicators for measuring this variable consist of 1) Lighting at work; 2) Aircirculation; 3) Noise; 4) Mechanical vibrations at work; 5) Security at work; 6) Comfort; 7) The leadership's concern for employees; 8) There is a concern between employees.

3) Motivation (X3)

Motivation is the encouragement for the workers of Mitra BPS Ngawi Regency to carry out their work to achieve the goals set by the BPS Ngawi Regency. The indicators to measure the motivation variables are: a) The duration of the activity; b) 
Frequency of activity; c) Persistence in activities; d) Fortitude, tenacity, and the ability to overcome obstacles and difficulties; e) Devotion and sacrifice to achieve the goal; f) The level of aspiration to be achieved in the activities carried out; g) The level of qualification of achievement or product (output) achieved from the activities carried out; $h$ ) Direction of attitude towards the target of the activity.

4) Work Productivity ( $Y$ )

Work productivity is the ability of the workers of Mitra BPS Ngawi Regency in producing a job or product compared to the input used. Indicators to measure it are a) The comparison between the present implementation and the historical implementation that does not show whether the current implementation is satisfactory or not, but only highlights whether the increase at is reduced and the level; b) Comparison of the implementation of one unit (individual task, section, process) with another. Measurements like this show relative achievement; c) Comparison of the present implementation with its target and this is best to focus the attention of the target and objectives.

\subsection{Population and Sampling}

As the population in this study is the entire Mitra BPS Power of Ngawi Regency which is 466 people. All members of the population were taken samples using the formula Slovin with a precision of $10 \%$ so that a sample of 82 people was obtained. The sampling technique used is simple random sampling or a simple random system.

\subsection{Data Collection Techniques}

In every research process, you need data. This data collection tool uses techniques: Observation, documentary, and questionnaire as the main technique.

\subsection{Data Analysis Techniques}

Data analysis in this study uses the Path Analysis Model of Decomposition, which analyzes the influence of causality between research variables (Riduwan: 2008). But previously conducted validity tests and reliability tests and normality tests.

\section{Results and Discussions 4.1 Validity Test}

The Validity Test in this study used the corrected item-total correlation technique, which correlates the score of each item with its total score. With a 2-sided test at a significance level of $a=5 \%$. As for criteria if $r$ calculates $\geq r$ table means valid question item, and vice versa if $r$ calculates $\leq r$ table with invalid question item. From the calculation results obtained the lowest $X 1$ correlation coefficient value of 0.472 , the lowest $X 2$ of 0.634 , the lowest $X 3$ of 0.576 , and the lowest $Y$ variable of 0.625 which are all greater than the table of 0.361 . So, all items for all variables are declared valid.

\subsection{Reliability Test}

This study's reliability test used the Alpha (Cronbach's) method. As for alpha (Cronbach's) testing provisions, if the reliability index is $>0.60$, it can be stated that the instrument is reliable. From the results of statistical calculations obtained the index of reliability $\mathrm{X} 1$ amounted to $0.864, \mathrm{X} 2$ amounted to $0.762, \mathrm{X} 3$ by 0.728 , and Variable $\mathrm{Y}$ by 0.849 . The reliability index numbers are all greater than 0.60 , so it can be stated that all the variables of this study are declared reliable.

\subsection{Normality Test}

The normality test uses the Kolmogorov-Smirnovmodel. The results of statistical calculations can be known from the KolmogorovSmirnov column which shows that the value of significance for compensation variables is 0.074 , the work environment is 0.082 , work motivation is 0.078 , and work productivity is 0.106 . So, the significance value of all variables is greater than 0.05 , so it can be stated that the data on all variables is a normal distribution.

\subsection{Discussion}

The hypothesis proposed in this study reads compensation, work environment, work motivation partially and simultaneously contribute significantly to the labor productivity of Mitra BPS Ngawi Regency.

Based on the results of partial statistical calculations for variable $\mathrm{X} 1$, as seen in table 3 (in the appendix) that the motivation compensation to work productivity obtained $\mathrm{t}$-calculate $=2,274$ with the value of probability (Sig) $=0.015<0.05$. This means that $\mathrm{Ho}$ is rejected and $\mathrm{Ha}$ is accepted. So, compensation partially contributes significantly to the labor productivity of Mitra BPS Ngawi Regency.

Based on the results of partial statistical calculations for variable $\mathrm{X} 2$, it is seen in table 3 (in the appendix) that the effect of the work environment on work productivity is obtained $t$-calculate $=2,266$ with probability value $(\mathrm{Sig})=0.027<0.05$. This means that 
Ho was rejected and Ha accepted. Therefore, the partial working environment contributes significantly to the labor productivity of Mitra BPS Ngawi Regency.

Based on the results of partial statistical calculations for variable $\mathrm{X} 3$, it is seen in table 3 (in the appendix) that the effect of work motivation on work productivity is obtained $t$-calculate $=2,114$ with null probability $(\mathrm{Sig})=0.035<0.05$. This means that Ho was rejected and ha accepted. So, work motivation partially contributes significantly to the labor productivity of Mitra BPS Ngawi Regency.

Based on calculations simultaneously obtained $\mathrm{F}$ calculates 10.458 with probability $(\mathrm{Sig})=0.000$, which means $<0.05$. This means ho or the null hypothesis is rejected and $\mathrm{Ha}$ or the work hypothesis is accepted, so it can be stated that compensation, work environment, work motivation simultaneously contributes significantly to the labor productivity of Mitra BPS Ngawi Regency.

\section{Conclusion}

Based on the results of the above analysis, it can be concluded that compensation, work environment, and motivation partially and simultaneously contribute significantly to the labor productivity of Mitra BPS Ngawi Regency.

\section{Suggestions}

It is empirically evident that compensation, work environment, and work motivation contribute significantly encourage work productivity. Therefore, BPS Ngawi Regency needs to pay attention to these three factors if you want to increase the labor productivity of BPS Partners of Ngawi Regency.

\section{References}

[1] Arikunto, S. 2007, Research Procedure: A Practical Approach, Jakarta, Rineka Cipta.

[2] Bolanle O, and Asabi, O. M, 2014, Compensation Management and Employees Performance in the Manufacturing Sector, A Case Study of a Reputable Organization in the Food and Beverage Industry IBOJO, International Journal of Managerial Studies and Research (IJMSR), Volume2, Issue 9, October 2014.

[3] Emmanuel E.Y., 2013, Relationship Between Compensation and Employee Productivity, Singaporean Journal of Business Economics and Management, Vol. 2 No. 1.

[4] Hasibuan, S.P. 2007. Revised Edition of Human Resource Management. Jakarta, Bumi Aksara

[5] James S., 2013, Productivity and Compensation: Growing Together, Backgrounder Journal, No. 2825, July 17.

[6] John M. 2012, Organization Behavior Structure Processes, EightEdition, Boston, Richard D Irwin Inc Homewood.

[7] Kumbadewi S., and Agus J. S. 2016, Influence of Age, Work Experience, Wages, Technology, and Work Environment on Work Productivity, Indonesian Management Journal, Vol.4, No. 1

[8] Riduwan M, 2008, How to Use and Interpret Path Analysis, Bandung, Alfabeta.

[9] Sedarmayanti K.,2011, Work Order and Work Productivity, Third Print, Bandung, Mandar Maju.

[10] Siti M. 2012, Driving Factors in Increasing the Productivity of Women's Labor Industry, Trade, and Services sector in East Kalimantan, Economic Forum, Vol. XV No. 2 July 2012

[11] Sugiyono M, 2004, Business Research Methods, Bandung, Alfabeta

[12] Vellina T., 2012, Analysis of the Influence of Education, Wages, Incentives, Social Security and Work Experience on Labor Productivity in Semarang City (Kec case study. Banyumanik and Kec. Gunungpati), Post-graduate research Undip, Semarang, Not published. 


\section{Appendix: Statistical Calculation Results}

Table 1: Summary Model

\begin{tabular}{|l|l|l|l|l|}
\hline Type & $R$ & R Square & $\begin{array}{l}\text { Adjusted } \\
\text { Square }\end{array}$ & $\begin{array}{l}\text { Std. Error of the } \\
\text { Estimate }\end{array}$ \\
\hline 1 & $.715^{\mathrm{a}}$ & .511 & .349 & 1.602 \\
\hline
\end{tabular}

a Predictors: (Constant), Motivation, Environment, Compensation

b Dependent Variable: Productivity

Table 2: ANOVA ${ }^{a}$

\begin{tabular}{|ll|l|l|l|l|l|}
\hline Type & Sum of Squares & Df & Mean Square & F & Sig. \\
\hline \multirow{4}{*}{1} & Regression & 12,782 & 3 & 1.822 & 10.458 & $.000^{\text {a) }}$ \\
& Residual & 74.192 & 79 & 3.102 & & \\
& Total & 86.974 & 79 & & & \\
\hline
\end{tabular}

a Predictors: (Constant), Motivation, Environment, Compensation

b Dependent Variable: Productivity

Table 3: Coefficients

\begin{tabular}{|c|c|c|c|c|c|c|c|}
\hline \multirow{2}{*}{\multicolumn{2}{|c|}{ Type }} & \multicolumn{2}{|c|}{ Unstandardized Coefficients } & \multirow{2}{*}{\multicolumn{2}{|c|}{\begin{tabular}{|l} 
Standardized \\
Coefficients
\end{tabular}}} & \multirow[t]{2}{*}{$\mathrm{t}$} & \multirow[t]{2}{*}{ Sig. } \\
\hline & & $B$ & Std. Error & & & & \\
\hline \multirow{4}{*}{1} & (Constant) & -8.417 & 7.728 & \multirow{4}{*}{\multicolumn{2}{|c|}{2.078}} & .258 & .394 \\
\hline & Compensatio & 1.327 & .467 & & & 2.724 & .015 \\
\hline & Milieu & 1.182 & .328 & & & 2.266 & .027 \\
\hline & Motivation & 1.090 & .187 & & & 2.114 & .035 \\
\hline
\end{tabular}

a. Dependent Variable: Productivity 